This article is licensed under the Creative Commons Attribution-NonCommercial 4.0 International License (CC BY-NC) (http://www.karger.com/Services/OpenAccessLicense). Usage and distribution for commercial purposes requires written permission.

\title{
An Autopsy Case of Edwardsiella tarda Meningoencephalitis
}

\author{
Takahiro Makino $^{a} \quad$ Isamu Sugano ${ }^{b} \quad$ Ikuo Kamitsukasa $^{\mathrm{a}}$ \\ aDepartment of Neurology, Chibaken Saiseikai Narashino Hospital, Narashino, Japan; \\ ${ }^{b}$ Department of Pathology, Chibaken Saiseikai Narashino Hospital, Narashino, Japan
}

\section{Keywords}

Meningoencephalitis · Edwardsiella tarda $\cdot$ Autopsy case $\cdot$ Alcoholic liver disease $\cdot$ Immune status

\begin{abstract}
A 62-year-old male with a history of alcohol abuse was admitted with a headache and rapidly progressing altered consciousness that led to coma over several hours. Blood and cerebrospinal fluid cultures were positive for Edwardsiella tarda. Despite prompt treatment initiation, the patient died on the third hospital day. Autopsy showed meningitis of the entire cerebrum with ventriculitis, and alcoholic fatty liver was observed. Clinicians should be cognizant of $E$. tarda meningoencephalitis, a rare presentation which can be associated with poor outcomes in patients with excessive alcohol consumption and alcoholic liver disease.

$$
\begin{aligned}
& \text { (c) } 2018 \text { The Author(s) } \\
& \text { Published by S. Karger AG, Basel }
\end{aligned}
$$
\end{abstract}

\section{Introduction}

Edwardsiella tarda is an anaerobic gram-negative bacillus associated with freshwater environments and animals. While E. tarda infections usually present with gastroenteritis, they 


\section{Case Reports in Neurology}

Makino et al.: An Autopsy Case of Edwardsiella tarda Meningoencephalitis

can occasionally lead to bacteremia or septicemia that is often fatal in patients with alcoholic liver disease [1, 2]. However, E. tarda has rarely been reported to cause bacterial meningitis [3-5]. We herein present the autopsy case of a patient with bacterial meningitis caused by $E$. tarda, which was fatal.

\section{Case Presentation}

A 62-year-old male progressing from headache and altered behavior to altered consciousness and stupor over several hours was admitted to our hospital. His medical history included excessive alcohol intake of approximately $800 \mathrm{~g}$ per week for a minimum of 20 years, and he indicated that he often cooked fish himself using an electric heater while consuming alcohol. He also had a pet turtle in his bedroom. He also had a history of pneumonia which was successfully treated 10 years ago and macrocytic anemia which was noted during a routine medical health screening.

On admission, his vital signs were as follows: body temperature, $39^{\circ} \mathrm{C}$; pulse rate, 120 beats per minute; and blood pressure, 142/65 mm Hg. He was confused, could not follow verbal commands, and exhibited neck stiffness. His pupils were round, $3 \mathrm{~mm}$ in diameter, and his light reflex was sluggish. Roving eye movements were observed. There was no obvious weakness in his extremities, and he did not have a positive Babinski sign.

Cranial computed tomography images showed a small hematoma with perifocal edema at the trigone of the left lateral ventricle (Fig. 1). Laboratory test results were as follows: white blood cells, $12,200 / \mathrm{mL}$; platelets, $6.9 \times 10^{4} / \mathrm{mL}$; red blood cells, $313 \times 10^{4} / \mathrm{mL}$; mean red blood cell volume, $109.9 \mathrm{fL}$; hemoglobin, $12.4 \mathrm{mg} / \mathrm{dL}$; C-reactive protein, $15.0 \mathrm{mg} / \mathrm{dL}$; aspartate aminotransferase, 1,047 IU/L; alanine aminotransferase, $203 \mathrm{IU} / \mathrm{L} ; \gamma$-glutamyl transpeptidase, $547 \mathrm{IU} / \mathrm{L}$; blood urea nitrogen, $29.4 \mathrm{mg} / \mathrm{dL}$; and creatinine, $2.25 \mathrm{mg} / \mathrm{dL}$. Examination of the cerebrospinal fluid (CSF) revealed a bloody appearance, with an opening pressure of $100 \mathrm{~mm}$ $\mathrm{H}_{2} \mathrm{O}$, a cell count of $2,683 / \mu \mathrm{L}$ with only polymorphonuclear cells, a protein concentration of $1,165 \mathrm{mg} / \mathrm{dL}$, and a glucose concentration of $0 \mathrm{mg} / \mathrm{dL}$. CSF Gram stain revealed many gramnegative bacilli which were phagocytosed by the polymorphonuclear leukocytes (Fig. 1b). Blood and CSF cultures were positive for E. tarda, which was susceptible to several antibiotics including meropenem. The definitive diagnosis was meningoencephalitis due to E. tarda infection. The patient was initiated on intravenous dexamethasone at $0.15 \mathrm{mg} / \mathrm{kg}$, followed by $2 \mathrm{~g}$ meropenem every $12 \mathrm{~h}$. Eight hours after admission, his blood pressure declined, and intravenous continuous infusion of dopamine was started; however, the blood pressure did not increase sufficiently. Nine hours after admission, the patient developed general tonic seizures, bilateral mydriasis with no light reflex, and an abnormal eye position without oculocephalic reflex. His consciousness deteriorated to deep coma, and $375 \mathrm{mg}$ fosphenytoin sodium hydrate was initiated. The CSF examination on the second hospitalization day revealed a cell count of $864 / \mu \mathrm{L}$ which included only polymorphonuclear leukocytes. Despite the reduction in the CSF cell count, the patient never regained consciousness and died from cardiopulmonary arrest despite resuscitation on the third hospitalization day. 


\section{Case Reports in Neurology}

Case Rep Neurol 2018;10:252-260

DOI: $10.1159 / 000492488$

2018 The Author(s). Published by S. Karger AG, Base www.karger.com/crn

Makino et al.: An Autopsy Case of Edwardsiella tarda Meningoencephalitis

\section{Pathological Findings}

Postmortem autopsy was performed $16 \mathrm{~h}$ after the death of the patient. The cerebrum weighed 1,350 g. Macroscopically, pus was observed to cover the entire arachnoid space (Fig. 2a). Sectioning of the cerebrum and the brainstem revealed oozing in the cortex, the subependymal zone of the lateral ventricles (Fig. 2b), and the tegmentum of the midbrain and the cerebellar cortex (Fig. 2c). Microscopic evaluation revealed inflammatory cell infiltration in the subarachnoid space of the cerebral sulcus (Fig. 3a) and the choroid plexus (Fig. 3b) as well as ventriculitis. Purulent diverticulitis was observed at the ascending colon with severe inflammatory involvement of the colonic wall (Fig. 3b), and alcoholic fatty liver disease was also present (Fig. 3d).

\section{Discussion}

This patient had a long history of alcohol consumption and presented with a deterioration of consciousness that progressed to deep coma over several hours. He was diagnosed with bacterial meningitis complicated with sepsis due to E. tarda infection, which followed a fatal course, and the patient died on the third hospital day despite prompt treatment initiation. The autopsy revealed bacterial meningoencephalitis accompanied by ventriculitis in addition to the alcoholic liver disease.

Bacterial meningitis, the inflammation within the subarachnoid space between the arachnoid and the pia mater, follows a fatal course in $15-25 \%$ of the cases. Globally as well as in Japan, more than $80 \%$ of the bacterial causes of meningitis are Streptococcus pneumoniae, Neisseria meningitidis, and Haemophilus influenzae [6, 7]. E. tarda, which caused meningitis in the present case, is a motile, anaerobic, gram-negative bacillus that is typically isolated from fresh or brackish water $[1,2]$. E. tarda generally causes gastroenteritis and is less frequently reported as an etiological agent of extraintestinal infections that often present as septicemia; other presentations include endocarditis, empyema, hepatobiliary infection, peritonitis, intraabdominal abscess, osteomyelitis, and wound infections [1]. Bacterial meningitis due to $E$. tarda has been reported in only a few cases [3-5] (Table 1). Sonnenwirth and Kallus [3] reported the case of a 36-year-old female who was on steroid therapy for idiopathic thrombocytopenic purpura and systemic lupus erythematosus. The patient developed high fever, nausea, and vomiting, which were followed by mental confusion, and CSF culture was positive for E. tarda. Tateno [4] reported the case of a 78-year-old male with E. tarda meningitis after consuming raw freshwater fish. Okubadejo and Alausa [5] reported a neonate who developed symptoms 10 days after normal birth and was diagnosed with $E$. tarda meningitis. All but one of the previously reported patients with E. tarda meningitis died. These cases highlight that, albeit rare, E. tarda meningitis has an extremely poor outcome, which should be recognized by clinicians.

There are 2 factors that might underlie E. tarda infection: route of exposure and the immune status of the patient. First, dietary factors, i.e., consumption of raw fish or meat, and environmental factors, i.e., brackish water, were reported to be involved in 10.4 and $12.9 \%$, respectively, of the reported cases with E. tarda bacteremia [2]. Contact with a pet turtle was also reported to be associated with E. tarda infection [8]. Additionally, patients infected with 


\section{Case Reports in Neurology}

Case Rep Neurol 2018;10:252-260

DOI: $10.1159 / 000492488$

(c) 2018 The Author(s). Published by S. Karger AG, Base www.karger.com/crn

Makino et al.: An Autopsy Case of Edwardsiella tarda Meningoencephalitis

E. tarda are often immunocompromised due to various reasons, such as oral steroid intake, diabetes mellitus, malignancy, alcoholic liver cirrhosis [1,2], and alcoholism [2]. In the current case, there are several possible routes of transmission for E. tarda, including consumption of undercooked fish and handling the pet turtle. The organisms might have entered the bloodstream of the patient via the purulent diverticulitis lesion observed during the autopsy, with subsequent septicemia due to excessive alcohol use.

The choice of antibiotics for bacterial meningitis is a critical decision that is based on the patient's background and the antimicrobial susceptibility of the causative organism. Considering the empirical choice of antibiotics for the bacterial meningitis in the present case, patients over the age of 50 years with alcohol abuse should be started on meropenem and vancomycin for Streptococcus pneumonia and Listeria monocytogenes as the most likely causative organisms $[7,9]$. Conversely, most antibacterial agents that target gram-negative bacteria, including $\beta$-lactam antibiotics, cephalosporins, and aminoglycosides, except for colistin, were reported to show efficacy against $E$. tarda. In patients with extraintestinal $E$. tarda infections, antibiotic combinations, such as cephalosporins plus aminoglycosides, have been used [1]. In the present case, vancomycin was not considered in addition to the initial antimicrobial therapy with meropenem which was assessed as effective based on the decreased CSF cell count.

The neuropathological findings of bacterial meningitis include massive brain edema, congested leptomeninges, and disseminated bleeding without pus formation in less than $24 \mathrm{~h}$, whereas pus formation and cloudy meninges manifest $48 \mathrm{~h}$ or more after the disease onset. Microscopically, inflamed meninges are observed, with the presence of neutrophils, some containing phagocytosed bacteria and others intermingling with bacteria in the subarachnoid space. The meningeal inflammation may develop into ventriculitis in severe cases [6]. The neuropathological findings of the current case corresponded to the pathological findings around 3 days after the onset of bacterial meningitis. Ventriculitis might be associated with severe meningeal inflammation caused by the E. tarda infection.

A study reported that 5 of 13 patients with infectious meningitis accompanied by ventriculitis that was confirmed by magnetic resonance imaging died [10]. The overall mortality rate with $E$. tarda bacteremia ranges from 44.6 to approximately $50 \%[1,2]$, and a literature review found that liver cirrhosis was an independent risk factor for death in E. tarda bacteremia [2]. The present case developed meningitis with ventriculitis and $E$. tarda bacteremia, which were accompanied by alcoholic liver disease that was confirmed during autopsy. These factors might have contributed to the fatal outcome in the current patient.

We presented the case of a patient with bacterial meningoencephalitis due to E. tarda infection, which may have been related to excessive alcohol consumption and being in contact with a pet reptile. E. tarda should be considered as a rare causative organism in suspicious bacterial meningitis in immunocompromised patients with pet reptiles, and patients should be started on appropriate antibiotics without delay. Meningoencephalitis of the entire cerebrum accompanied by ventriculitis in the current patient with alcoholic liver disease confirmed during autopsy might have contributed to the fatal outcome. Public health initiatives should also consider instructions for individuals consuming excessive alcohol to avoid keeping pet animals inhabiting freshwater environments, with the goal of preventing E. tarda infections that are often fatal. 


\section{Acknowledgment}

We thank Dr. Sugano for pathological evaluation of the specimens. The authors would like to thank Enago (www.enago.jp) for the English language review.

\section{Statement of Ethics}

The patient provided informed consent to participate in this paper for any figures, which was approved by the institutional review board.

\section{Disclosure Statement}

The authors have no conflicts of interest to declare.

\section{Funding Sources}

The authors have no funding sources.

\section{Author Contributions}

Takahiro Makino wrote the initial draft of the manuscript. Takahiro Makino and Ikuo Kamitsukasa contributed to analysis and interpretation of the data. Takahiro Makino and Ikuo Kamitsukasa contributed to data collection and interpretation and critically reviewed the manuscript. All authors approved the final version of the manuscript and agree to be accountable for all aspects of the work in ensuring that questions related to the accuracy or integrity of any part of the work are appropriately investigated and resolved.

\section{References}

1 Janda JM, Abbott SL. Infections associated with the genus Edwardsiella: the role of Edwardsiella tarda in human disease. Clin Infect Dis. 1993 Oct;17(4):742-8.

2 Hirai Y, Asahata-Tago S, Ainoda Y, Fujita T, Kikuchi K. Edwardsiella tarda bacteremia. A rare but fatal waterand foodborne infection: review of the literature and clinical cases from a single centre. Can J Infect Dis Med Microbiol. 2015 Nov-Dec;26(6):313-8.

3 Sonnenwirth AC, Kallus BA. Meningitis due to Edwardsiella tarda. First report of meningitis caused by E. tarda. Am J Clin Pathol. 1968 Jan;49(1):92-5.

4 Tateno T. A case of the bacterial meningitis due to Edwardsiella tarda. Rinsho Shinkeigaku. 2001;41:247. Japanese.

5 Okubadejo OA, Alausa KO. Neonatal meningitis caused by Edwardsiella tarda. BMJ. 1968 Aug;3(5614):3578.

6 Deckert M. Bacterial infection. In: Love S, Budka H, Ironside JW, Perry A, editors. Greenfield's Neuropathology. Volume 2. 9th ed. London: CRC Press; 2015. pp. 1192-203. 


\section{Case Reports in Neurology}

\begin{tabular}{l|l} 
Case Rep Neurol 2018;10:252-260 \\
\hline DOI: 10.1159/000492488 & $\begin{array}{l}\text { (c) 2018 The Author(s). Published by S. Karger AG, Basel } \\
\text { www.karger.com/crn }\end{array}$ \\
\hline
\end{tabular}

7 Kamei S. Current Clinical Management of Bacterial Meningitis. Brain Nerve. 2015 Jul;67(7):787-98. Japanese.

8 Nagel P, Serritella A, Layden TJ. Edwardsiella tarda gastroenteritis associated with a pet turtle. Gastroenterology. 1982 Jun;82(6):1436-7.

9 Weisfelt M, de Gans J, van der Ende A, van de Beek D. Community-acquired bacterial meningitis in alcoholic patients. PLoS One. 2010 Feb;5(2):e9102.

10 Fujikawa A, Tsuchiya K, Honya K, Nitatori T. Comparison of MRI sequences to detect ventriculitis. AJR Am J Roentgenol. 2006 Oct;187(4):1048-53.
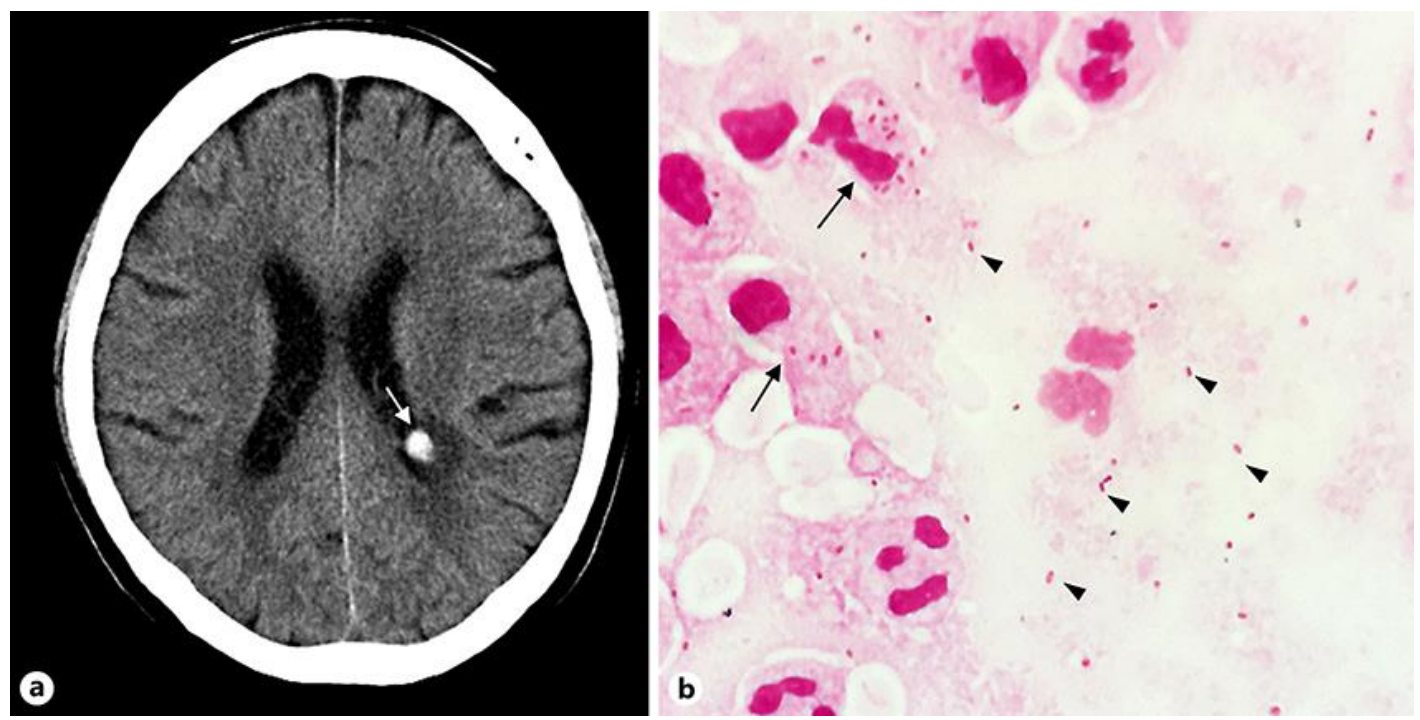

Fig. 1. a A computed tomography image of the cerebrum shows a small hematoma with perifocal edema as a hyperdense round lesion surrounded by a hypodense rim (white arrow) in the wall of the left lateral ventricle. $\mathbf{b}$ Gram staining of the cerebrospinal fluid shows many gram-negative bacilli (arrowheads). Some polymorphonuclear leukocytes appear to have phagocytosed the bacilli (arrows). 


\section{Case Reports in Neurology}
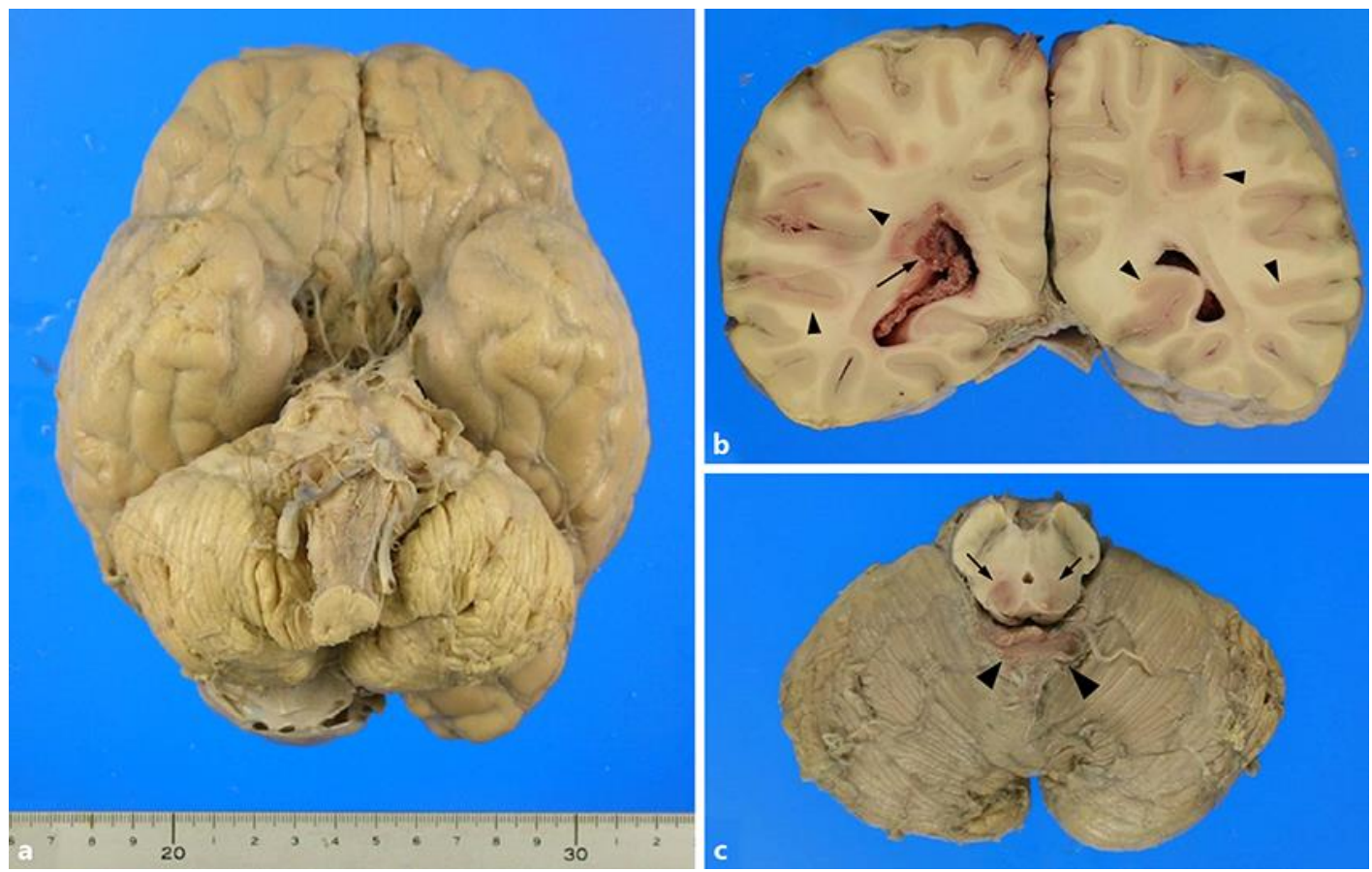

Fig. 2. a Inferior view of the brain by gross examination shows the cloudy appearance of the leptomeninges of the entire cerebrum and the basal cistern. The sections of the cerebrum (b) and the brainstem at the level of the midbrain (c) show edematous changes with oozing in the cerebrum (b, arrowheads), the cerebellar cortex (c, arrowheads), and the tegmentum of the midbrain (c, arrows). A hematoma in the white matter of the left lateral ventricle (b, arrow) can also be observed. 


\section{Case Reports in Neurology}


Fig. 3. Microscopic images of the tissue sections are shown. Specimens are from the cerebral cortex (a, b), the colon (c), and the liver (d). a Infiltration of the inflammatory cells in the subarachnoid space of the cerebral sulcus (arrowheads) between the cerebral cortex at the top and bottom of the image can be observed. b Inflammatory cells are also observed in the choroidal plexus. c Purulent necrotic diverticulitis with the inflammatory involvement of the colonic wall (arrow) can be observed. $\mathbf{d}$ Fatty liver changes can also be observed. 


\section{Case Reports in Neurology}

Case Rep Neurol 2018;10:252-260

DOI: $10.1159 / 000492488$

(C)

(C) 2018 The Author(s). Published by S. Karger AG, Base www.karger.com/crn

Makino et al.: An Autopsy Case of Edwardsiella tarda Meningoencephalitis

Table 1. Reported cases of meningitis due to infection with Edwardsiella tarda

\begin{tabular}{|c|c|c|c|c|c|c|c|c|c|}
\hline \multirow[t]{2}{*}{ Reference } & \multirow[t]{2}{*}{ Age } & \multirow[t]{2}{*}{ Sex } & \multirow{2}{*}{$\begin{array}{l}\text { Comorbid- } \\
\text { ity }\end{array}$} & \multirow{2}{*}{ Risk } & \multirow[t]{2}{*}{ Clinical presentation } & \multicolumn{2}{|l|}{ CSF examination } & \multirow[t]{2}{*}{ Treatment } & \multirow{2}{*}{$\begin{array}{l}\text { Out- } \\
\text { come }\end{array}$} \\
\hline & & & & & & cell count, $/ \mu$ & $\begin{array}{l}\text { glucose } \\
\text { concentration, } \\
\mathrm{mg} / \mathrm{dL}\end{array}$ & & \\
\hline 3 & 36 years & $\mathrm{f}$ & SLE, ITP & $\begin{array}{l}\text { steroid } \\
\text { therapy }\end{array}$ & $\begin{array}{l}\text { high fever, hematemesis, } \\
\text { nausea, vomiting }\end{array}$ & NA & NA & NA & death \\
\hline 4 & 78 years & $\mathrm{m}$ & NA & $\begin{array}{l}\text { eating raw } \\
\text { fish }\end{array}$ & diarrhea, chills, high fever & $\begin{array}{l}1,178, \text { polymor- } \\
\text { phonuclear }\end{array}$ & 13 & ABPC and CTX & alive \\
\hline 5 & 1 month & $\mathrm{f}$ & none & none & high fever, weight loss & $\begin{array}{l}9,625, \text { polymor- } \\
\text { phonuclear }\end{array}$ & NA & $\begin{array}{l}\text { penicillin, } \\
\text { chroramphenicol, } \\
\text { sulphadiazine, } \\
\text { streptomycin }\end{array}$ & death \\
\hline $\begin{array}{l}\text { Present } \\
\text { case }\end{array}$ & 62 years & $\mathrm{m}$ & none & $\begin{array}{l}\text { alcohol intake, } \\
\text { keeping a } \\
\text { turtle }\end{array}$ & $\begin{array}{l}\text { high fever, progressive } \\
\text { loss of consciousness }\end{array}$ & $\begin{array}{l}2,683, \text { polymor- } \\
\text { phonuclear }\end{array}$ & 0 & meropenem & death \\
\hline
\end{tabular}

CSF, cerebrospinal fluid; SLE, systemic lupus erythematosus; ITP, idiopathic thrombocytopenic purpura; NA, not available; ABPC, ampicillin; CTX, cefotaxime. 